\begin{tabular}{|c|c|c|}
\hline UUN 109 20) ENGINEERING DATA TRANSMITTAL & 1. EDT & $621^{\text {Peog }}$ of 12 \\
\hline
\end{tabular}

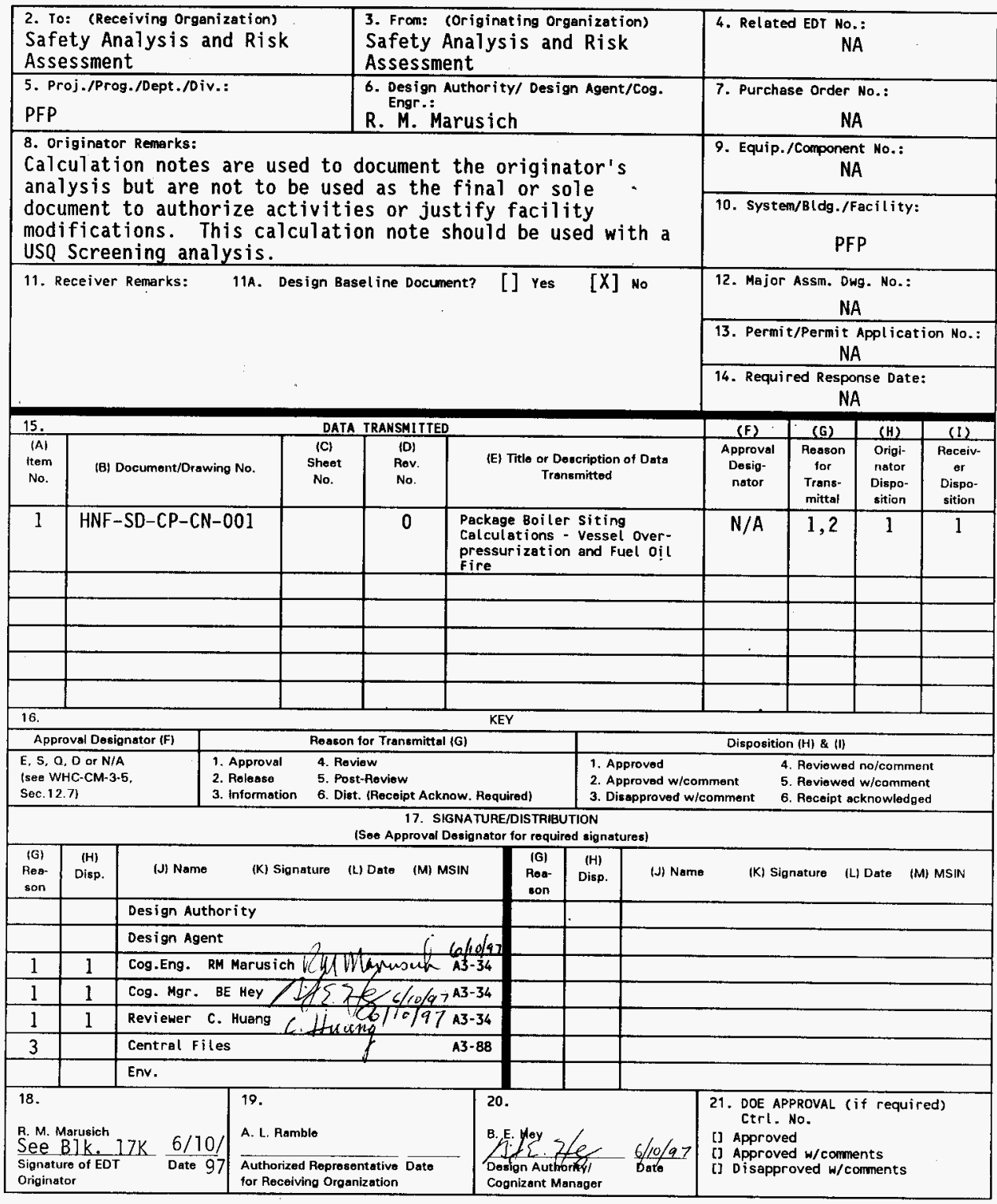




\title{
Package Boiler Siting Calculations - Vessel Overpressurization and Fuel Oil Fire
}

\author{
R. M. Marusich \\ Fluor Daniel Northwest, Richland, WA 99352 \\ U.S. Department of Energy Contract DE-AC06-96RL13200
}

$\begin{array}{lll}\text { EDT/ECN: } & 621242 & \text { UC: } 2000 \text { y } \\ \text { Org Code: } & 04 E 00 & \text { Charge Code: F4CF } \\ \text { B\&R Code: } & \text { EW3130010 } & \text { Total Pages: } 39\end{array}$

Key Words: Package Boiler, Fire, Vessel Overpressurization

Abstract: The purpose of this calculation note is to provide the basis for the siting of a package boiler outside the Plutonium Finishing Plant.

TRADEMARK DISCLAIMER. Reference herein to any specific comercial product, process, or service by trade name, trademark, manufacturer, or otherwise, does not necessarily constitute or imply its endorsement, recommendation, or favoring by the United States Govermment or any agency thereof or its contractors or subcontractors.

Printed in the United States of America. To obtain copies of this document, contact: Document Control Services, P.0. Box 950, Mailstop H6-08, Richland WA 99352, Phone (509) 372-2420;

Fax (509) 376-4989.
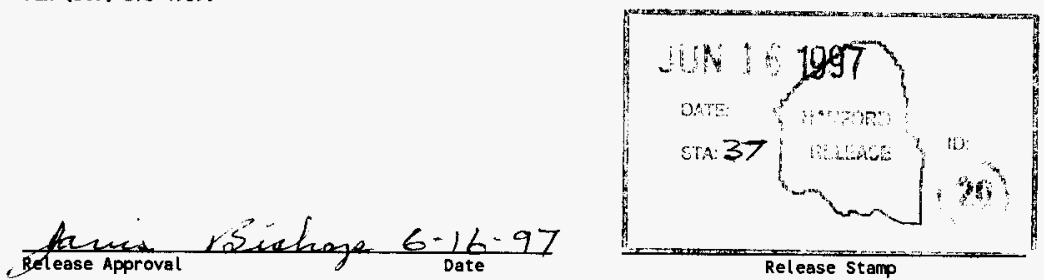

Approved for Public Release 
HNF-SD-CP-CN-001, Rev. 0

\section{Package Boiler Siting \\ Calculations - Vessel \\ Overpressurization and \\ Fuel Oil Fire}

R. M. Marusich

Fluor Daniel Northwest

June 6, 1997

Page 2 of 39 
HNF-SD-CP-CN-001, Rev. 0

\section{Purpose}

The purpose of this calculation is to provide the basis for the siting of a package boiler to be used to supply steam to the Plutonium Finishing Plant.

\section{Methodology}

Standard engineering textbooks and handbooks supplied the equations and figures used in the analysis.

A standard methodology taken from the explosives manual used at the Pantax plant (DOE 1992) is used to determine the shock overpressure, impulse and their effect on steel panels, block walls and people. The methodology relates shock overpressure and the impulse as a function of distance to experiments on bursting vessels. The methodology uses scaled dimensionless parameters.

A standard methodology taken from DOE (1992) is used to determine the initial fragment velocity for fragments from the burst vessel. Data showing an empirical fit to TNT casing data is used to determine the initial velocity. A standard method from the Army Handbook for effects of the use of conventional explosives (Army 1986) is used to determine breach thickness as a function of striking velocity and striking velocity as a function of initial velocity and fragment size.

The methodology for the effects of a large diesel fuel fire is taken from a chapter of the Fire Protection Handbook concerning this subject. The methodology uses a number of empirical correlations and charts to determine the radiant heat flux and the effect of radiant heating on people.

Simple heat transfer equations are used to determine wall temperature and heat losses.

The methodology used to determine the overpressure due to a deflagration resulting from ignition of a large stoichiometric quantity of fuel $0 i 1$ aerosol was taken from experiments. In these experiments, stoichiometric quantities of flammable gas are ignited inside balloons. The pressure is recorded at varying distances. An empirical fit is made to the data (Kogarko 1966).

A copy of the pertinent pages of the references used are on file with the author. These references must be consulted in any effort to upgrade or change these calculations as almost all of the data comes from graphs which provide the results of a series of experiments or graphs having scaled dimensionless parameters for axes.

\section{Assumptions}

The following is assumed:

A. The fuel oil tank can hold 40,000 gallons of No. 2 diesel fuel oil (per vendor). 
HNF-SD-CP-CN-001, Rev. 0

B. The boiler tank dimensions are per the vendor (78 inch ID, 79 inch OD, 225 inch long).

C. The major siting concerns are shockwave due to boiler vessel burst as a result of overpressurization, fire due to diesel fuel tank leak, and deflagration due to ignition of diesel fuel oil vapor or aerosol.

D. The boiler is assumed to be empty at the start of the overpressurization accident so as to maximize the energy at burst. The boiler vessel is assumed to burst at its peak bursting pressure. The peak pressure occurs when the cylindrical shell ruptures at a location away from the seam. The head will separate from the vessel at a lower pressure. A seam in the cylindrical shell will also rupture at a lower pressure.

E. The diesel fuel tank is assumed to rupture with flow outside the berm. The pool is assumed to form quickly, spread until it is one inch deep and be ignited at that point. A separate case is also analyzed in which the fuel remains in the berm, and is ignited there.

F. The building that houses the package boiler is assumed to contain a stoichiometric concentration of fuel oil vapor or aerosol prior to ignition.

G. No credit is taken for the effect of the sheet steel building which encloses the boiler. Note that should vessel overpressurization, external fuel tank rupture event (e.g., seismic event, vehicle impact or external missile), or fuel oil deflagration occur, the building will afford little protection.

H. No formal hazards identification procedure was performed to identify the potential fire and explosion hazards. Instead it was postulated that the accidents having the greatest potential for damage were the 40,000 gallon diesel fuel oil fire, vessel overpressurization followed by rupture, and deflagration of a large quantity of diesel fuel oil vapor or aerosol.

IV. Input Data

See attached calculations.

\section{v. Calculations}

See attached. 
HNF-SD-CP-CN-001, Rev. 0

\section{Results and Conclusions}

Three conclusions came as a result of this study. The first conclusion is that the boiler must be located at least $50 \mathrm{~m}$ from an important building made up of corrugated steel sheet walls and at least $30 \mathrm{~m}$ from important buildings made up of block walls to prevent collapse of these walls due to shock pressure.

The second conclusion is that a one inch deep pool containing 40,000 gallons of fuel oil centered $50 \mathrm{~m}$ from a sheet steel wall insulated on one side produces unacceptable wall temperatures and effects on people near the wall. Therefore the berm must be protected or shown to have adequate structural capacity against all accidents that cause berm and tank failure. Examples of such accidents are vehicle impact, seismic event and external missiles.

The third conclusion is that it is possible for shrapnel to penetrate steel walls that are $50 \mathrm{~m}$ away. The calculational methods are such that protection against this event is not afforded by placement further away. Instead standard boiler overpressure controls coupled with a discussion of the conservative nature of the calculation (discussed in the attached calculation) and orientation of the boiler such that the vessel heads as well as small equipment (e.g., valves) attached to the vesse 1 are not pointing at an important building is all that can be done to show adequate protection.

An important observation that also came out of the review of the references was that the diesel fuel oil tank must be protected from heating from long duration heat sources such as range fires or large vehicle fires. Prolonged heating of the tank could result in a BLEVE (boiling liquid expanding vapor explosion) which could result in greater than acceptable overpressures and radiant heat loads. 
HNF-SD-CP-CN-001, Rev. 0

References:

Army 1986, "Fundamentals of Protective Design for Conventional Weapons," TM 5855-1, Department of the Army, Washington D.C.

Avallone, E. A., Baumeister, T., 1987, "Standard Handbook for Mechanical Engineers," McGraw-Hill Book Company, New York, NY.

Baker, W. E., Cox, P. A., Westine, P. S., Kulesz, J. J., Strehlow, R. A., 1983, "Explosions Hazards and Evaluation," Elsevier Scientific Publishing, New York, NY.

Brasie, W. C., Simpson, D. W., 1968, "Guidelines for Estimating Damage Explosion (sic)," Loss Prevention, pages 91-102, American Institute of Chemical Engineers, New York, NY.

$D O E$, 1992, "A Manual for the Prediction of Blast and Fragment Loadings on Structures," DOE/TIC-11268, U.S. Department of Energy, Albuquerque, NM.

Halverson, M. A., Mishima, J., 1986, "Initial Concepts on Energetics and Mass Releases During Non-Nuclear Explosive Events in Fuel Cycle Facilities," NUREG/CR-4593, U.S. Nuclear Regulatory Commission, Washington D.C.

Kanury, A. M., 1975, "Introduction to Combustion Phenomena," Gordon and Breach Science Publishing, New York, NY.

Kirk-Othmer, 1994, "Encyclopedia of Chemical Technology," Wiley Interscience, New York, NY.

Kogarko, S. M., Adushkin, V. V., Lyamin, A. G., 1966, "An Investigation of Spherical Detonations of Gas Mixtures," International Chemical Engineering, volume 6 , No. 3 .

Megyesy, E. F., 1973, "Pressure Vesse1 Handbook," Pressure Vessel Handbook Publishing, Tutsa, OK.

SFPE, 1988, "SFPE Handbook of Fire Protection Engineering, " Society of Fire Protection Engineers, Boston, MA.

Steiner, K., 1950, "0il Burners," McGraw-Hill Book Company, New York, NY.

Zabetakis, M. G., 1965, "Flammability Characteristics of Combustible Gases and Vapors," Bulletin 627, Bureau of Mines, Washington D. C. 
(2) 22-141 50 SHEETS

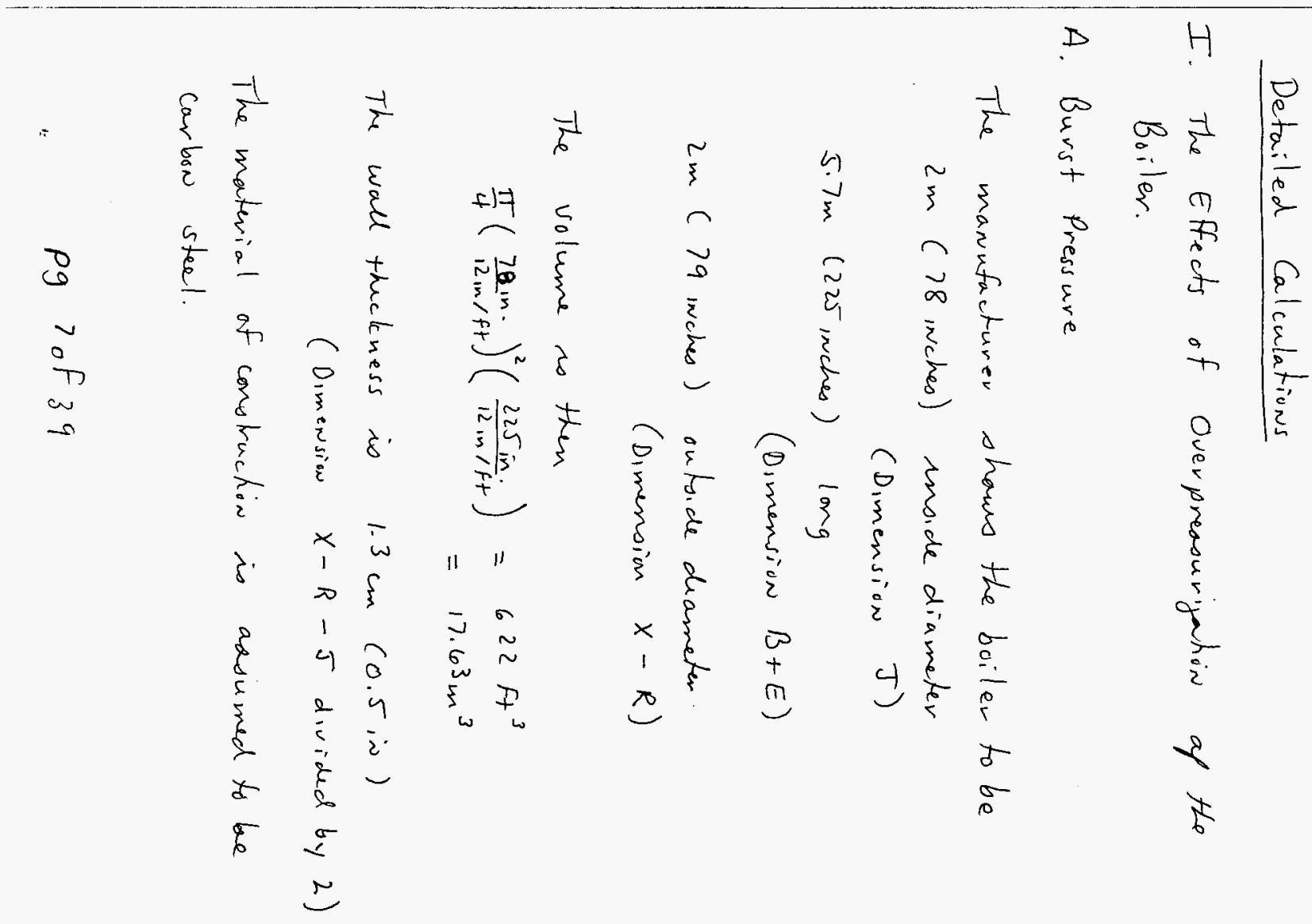


$\infty$
$\infty$
$\infty$
$\infty$
$\infty$
-1

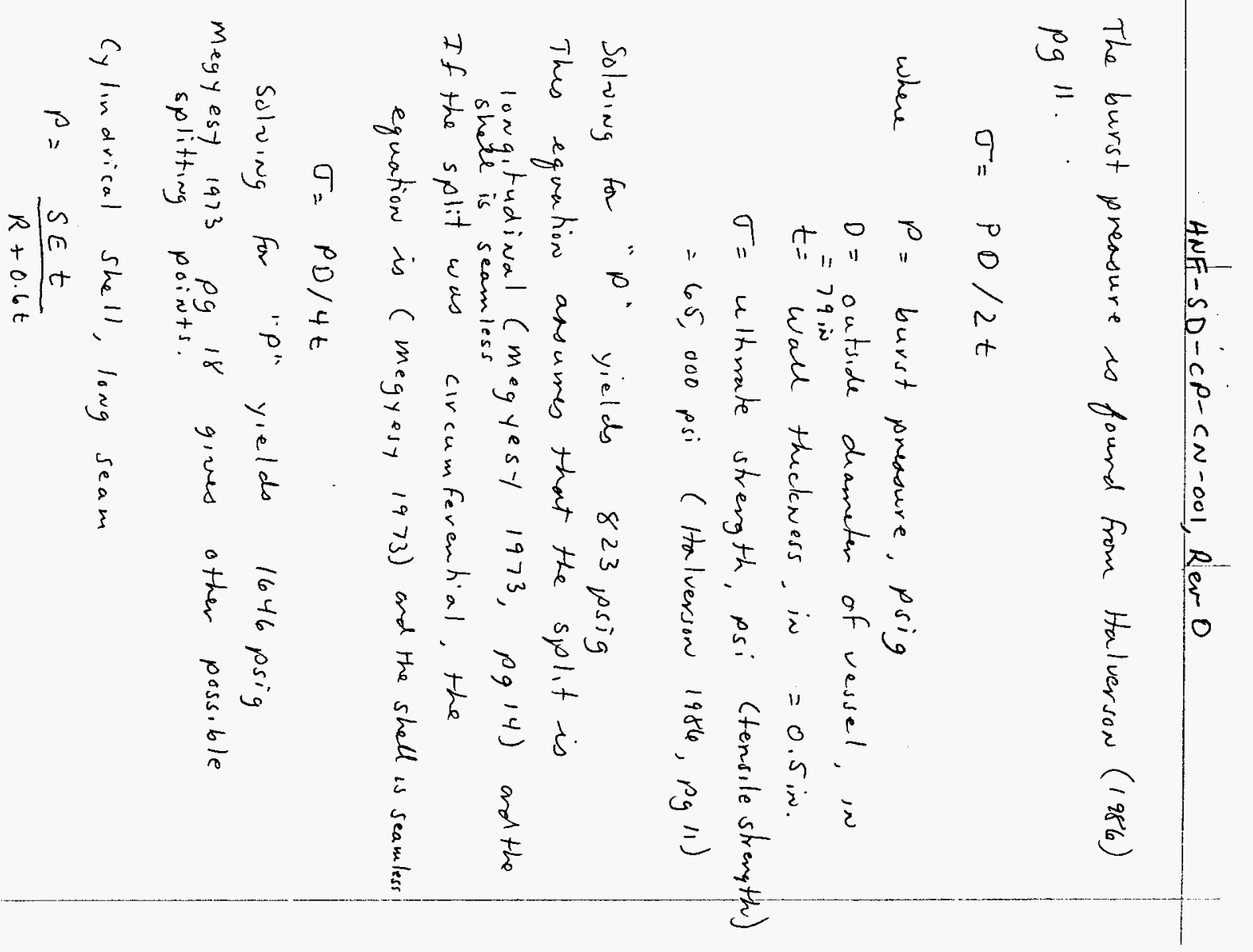




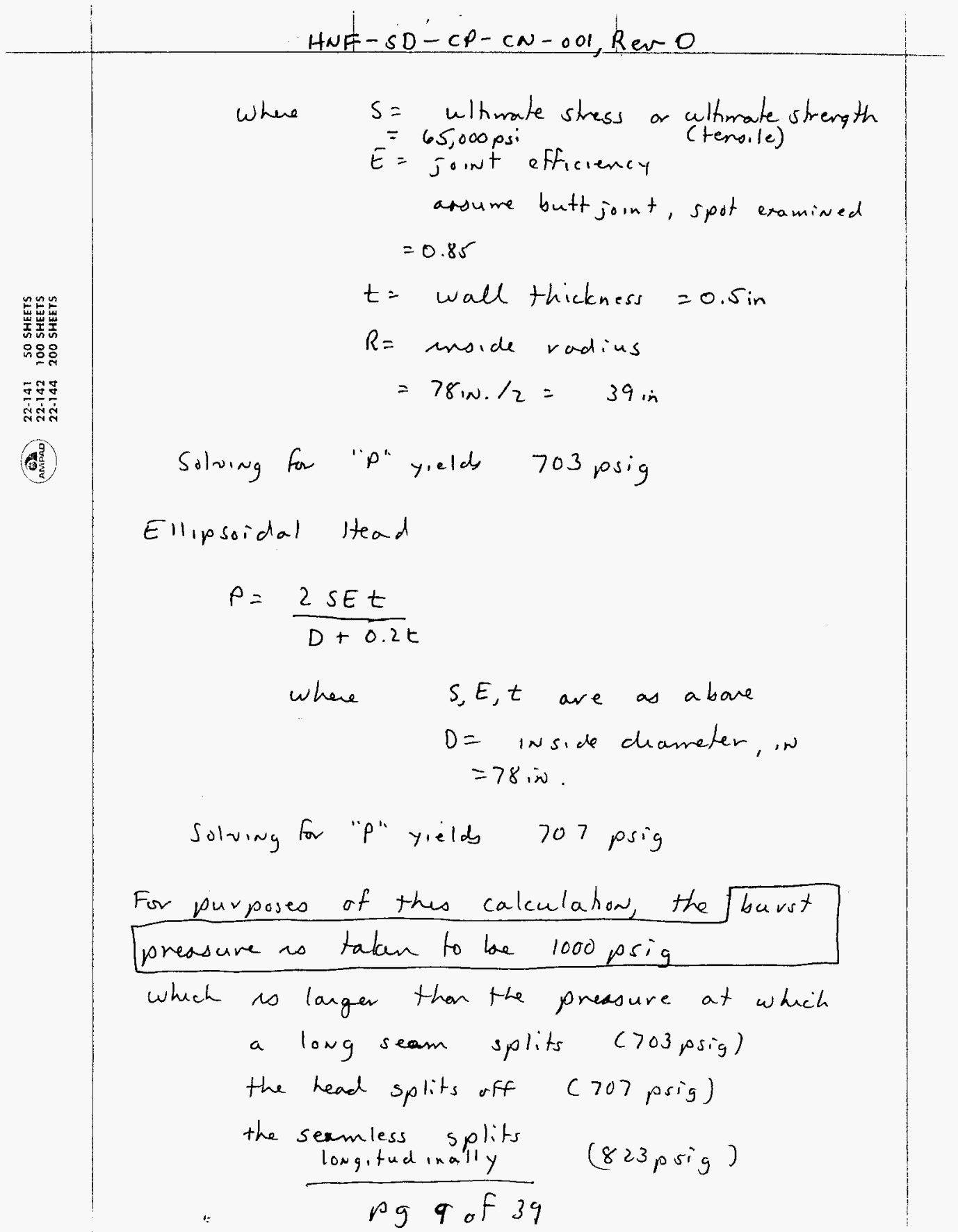


రె

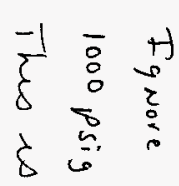

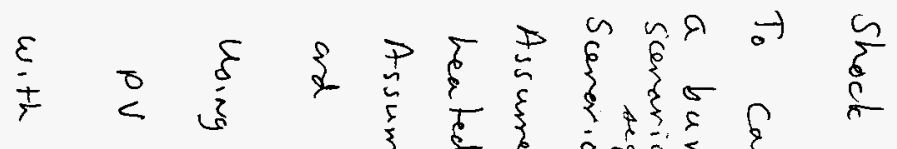

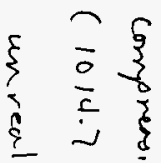

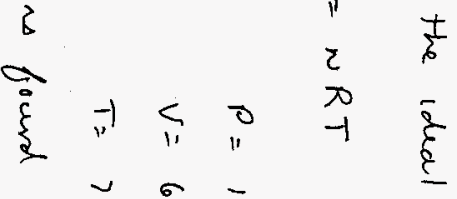

o

in







$\stackrel{\sim}{\circ}$

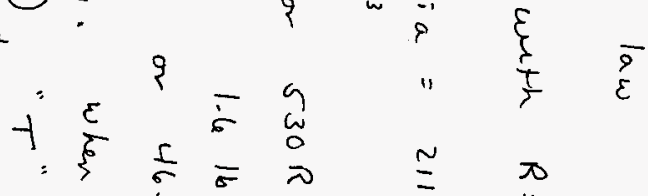

$$
\begin{aligned}
& \text { दू }
\end{aligned}
$$

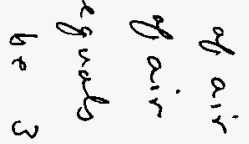

$$
\begin{aligned}
& \text { ปึ }
\end{aligned}
$$



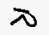

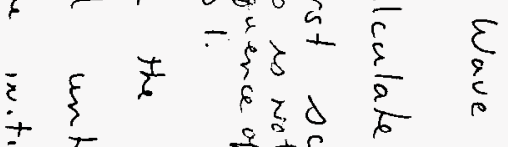

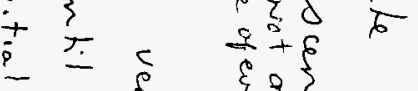$$
\text { ई ईदु ई ई ई }
$$

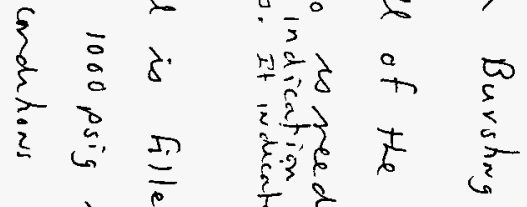$$
\text { द है ह ते है }
$$

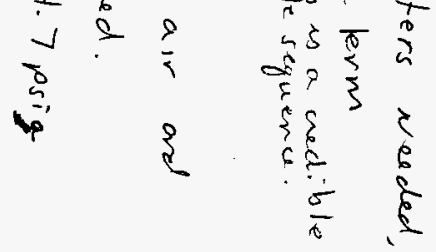


HNF-SD-CP-CN-001 Rev 0

Scenario 2. Assume the flue outlet is blocked and the flue gas in let lets in air but does not allow gas to escape. Assure that the tubes carrying the flue gas fall and that the flue gas mixes will the air. Assume that the air ard gas reach the burner temperature.

Assume a burner (that is flame) temperature of 3000 R ("Producer gas" or "blast furnace gas" flame temperature per Avallone ard Baumeister. 1987, pg 4-33)

The results in a value for " $n$ " of

$$
\begin{aligned}
& N=19.62 \quad \mathrm{~b} \text {-moles }(1.6 \text { is a ir) } \\
& T=3000 \mathrm{R} \\
& V=622 \mathrm{Ft}^{3} \\
& P=1014.7 \text { wi ia }
\end{aligned}
$$

This is what will be used in the calculations for shock pressure.

$$
\operatorname{pg} 11 \text { of } 39
$$




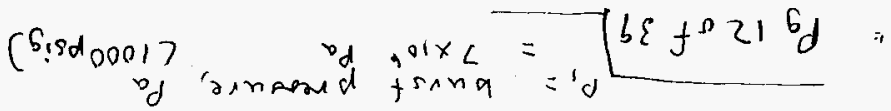

$$
\begin{aligned}
& \wedge\left(\frac{1-l}{\partial-\frac{d}{d}}\right)=3 \\
& \text { Dd } 5^{01 \times \varepsilon 10.1=} \\
& \text { by 'ampoond simpdoacy }=i d \\
& m g \%= \\
& \varepsilon+\Perp \frac{\varepsilon}{\hbar}=\varepsilon^{m} \varepsilon g-L 1
\end{aligned}
$$

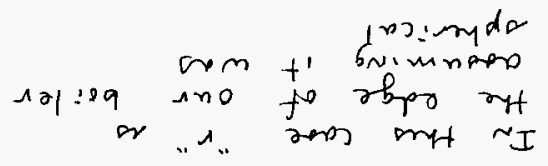

$$
\begin{aligned}
& m \text { 'tomere to triod } \\
& \text { ift if of roupone }=1 \text { raym } \\
& \varepsilon / 1 \Rightarrow / \varepsilon / 10 \\
& \text { d] af mies lats } \\
& \text { no amo im } \underline{y} \\
& \text { af Sd beyarov anans to hamual out ho } \\
& \text { anans youm pry of pase wh tray } \\
& \text { sasnom } \\
& \text { asim-drfs ow serpanoud papaso fo }
\end{aligned}
$$

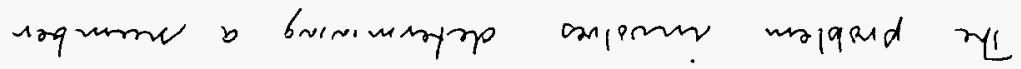

$$
\begin{aligned}
& \text { 902-spz bol us molgerd aphues ryt } \\
& \text { pes } \varepsilon s 1 \text { - sthl bd (Es61) ropog may }
\end{aligned}
$$

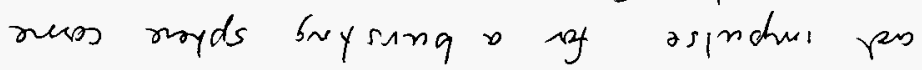

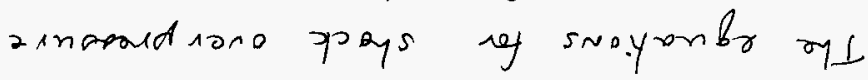




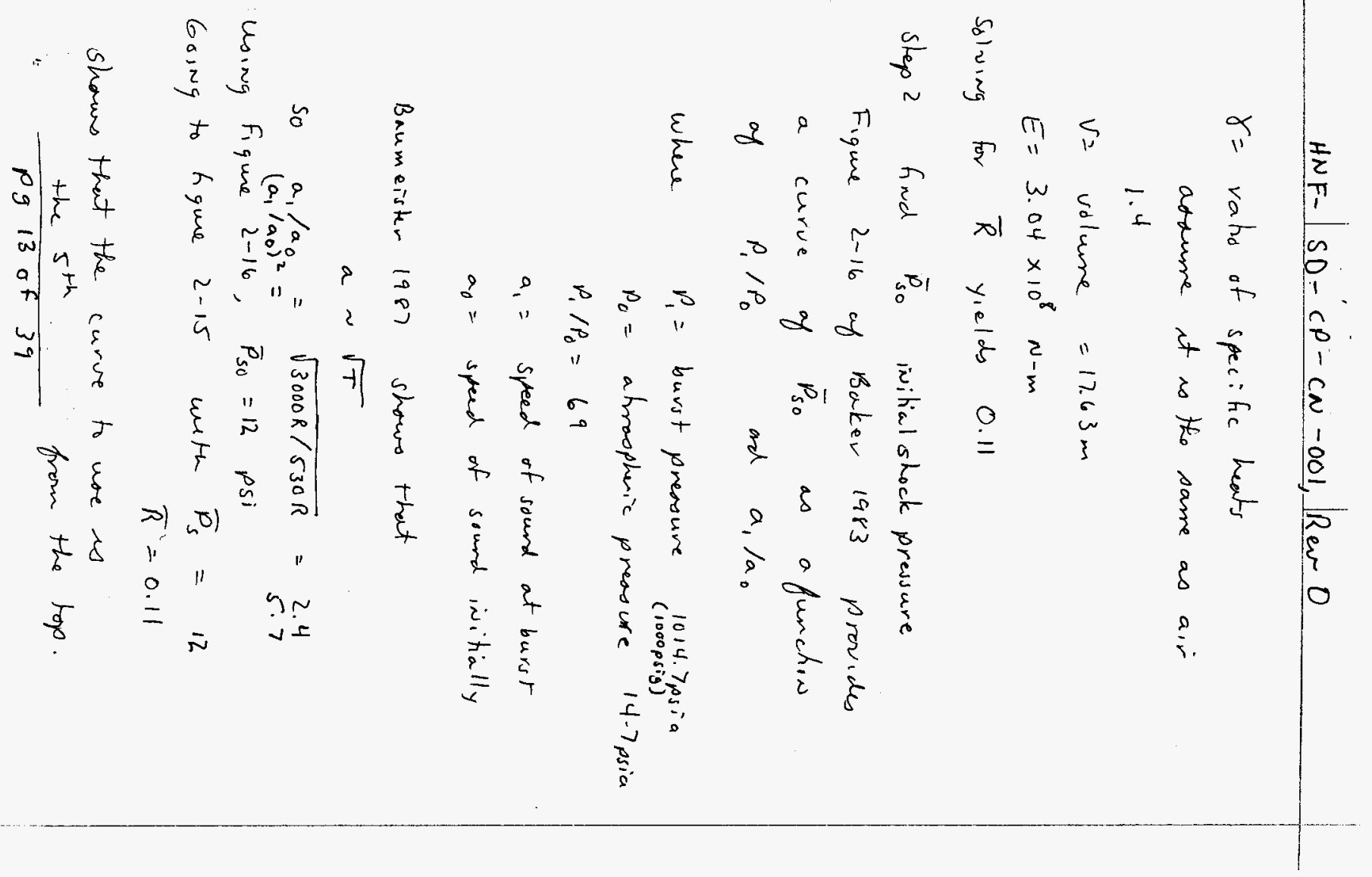


$\quad H N F-\mid S D-C P-C N-001$, Rev 0

Step 3 Now solve for $P$ given values of $R$.

Recall

$$
\begin{aligned}
& \bar{R}=r P_{0}^{1 / 3} / E^{1 / 3} \\
& =r(0.07) \\
& \bar{p}_{s}=\left(p_{s}-p_{0}\right) / p_{0} \quad \text { pg } 206 \\
& P_{s}=\text { pressure at " } r \text {. } \\
& P_{0}=\text { atrosphtevic pressure } \\
& \bar{p}_{s}\left(P_{0}\right)=p_{s}-p_{0}=\text { oven perogume or } \\
& \text { differential pressure }
\end{aligned}
$$

Using Figure 2-15

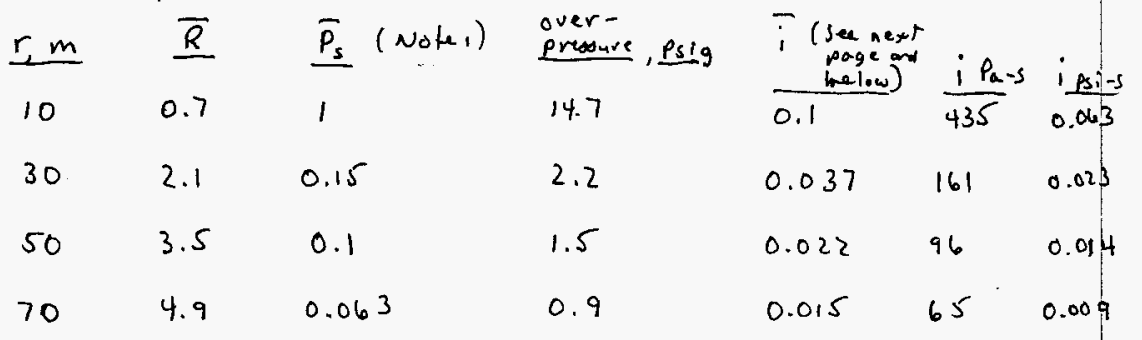

Noted values of $\bar{R}$ above 3 use $\log \left(\bar{P}_{5}\right)=-1.3 \log \bar{R}-0.3$ (extrapolation of top curve of Fig $2-15)$.

The impulse well be seeded for calculations involving effects on people. The impulse ss found on Figure 2-19

pg 14 of 39 


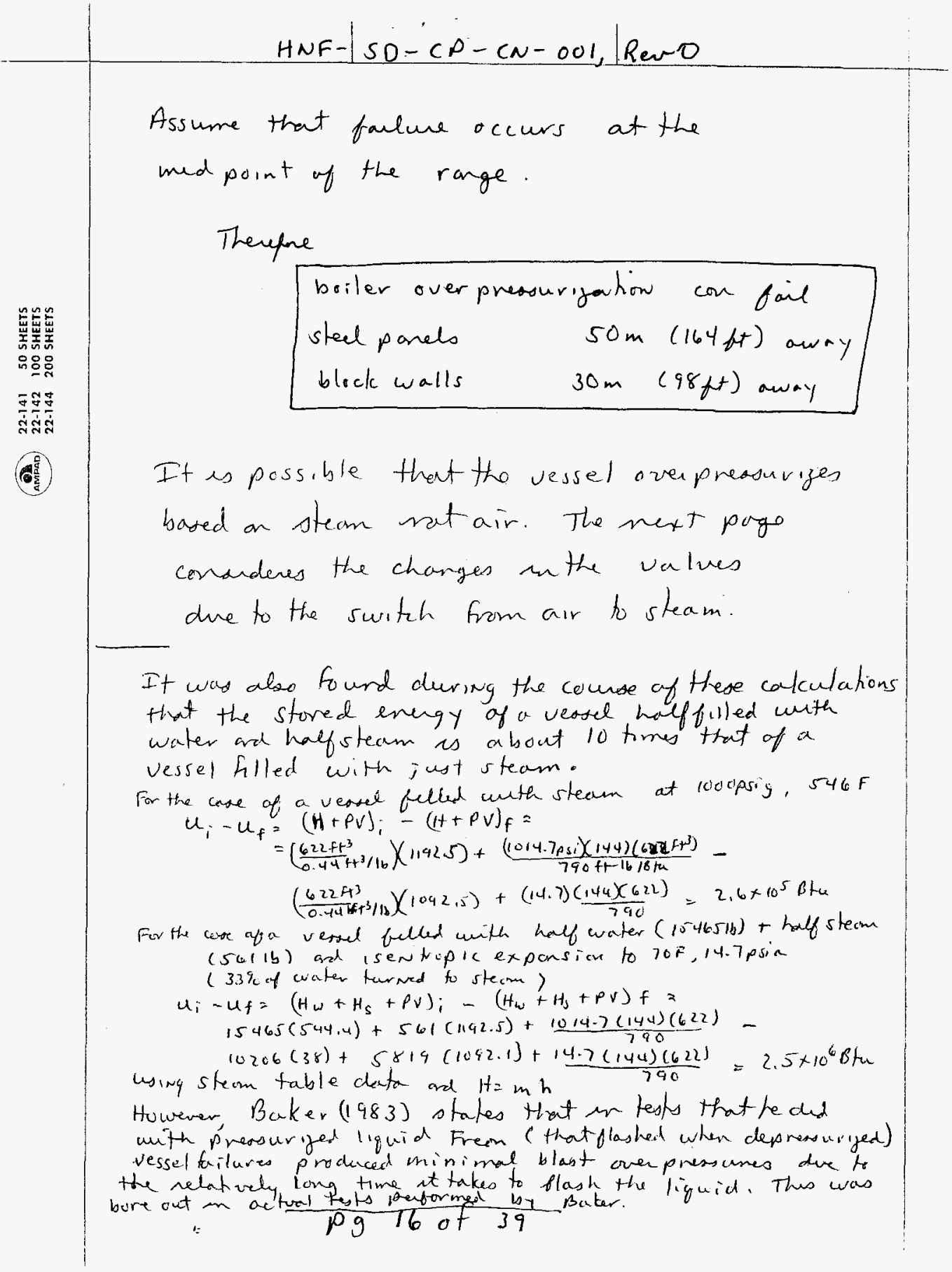




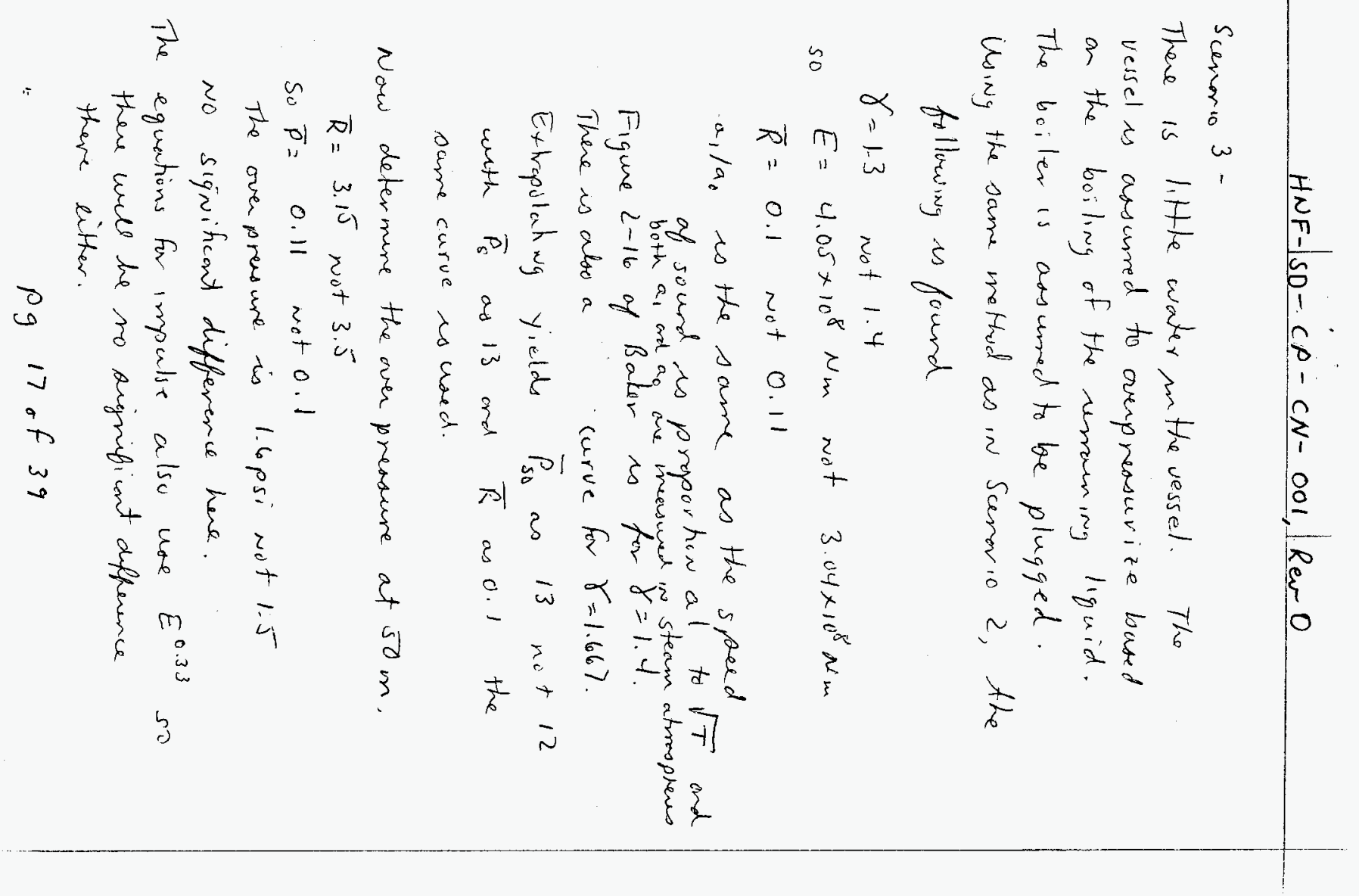




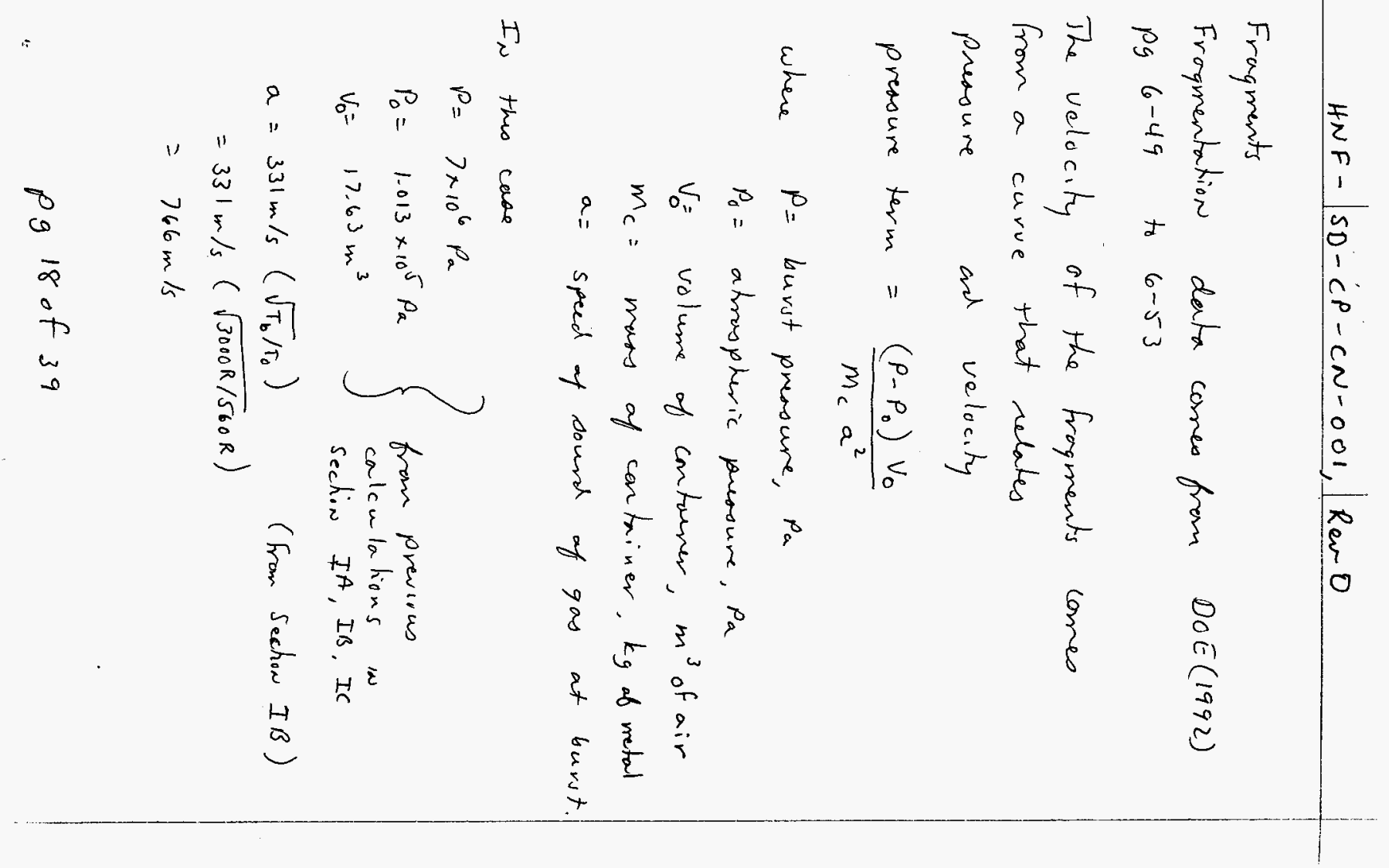




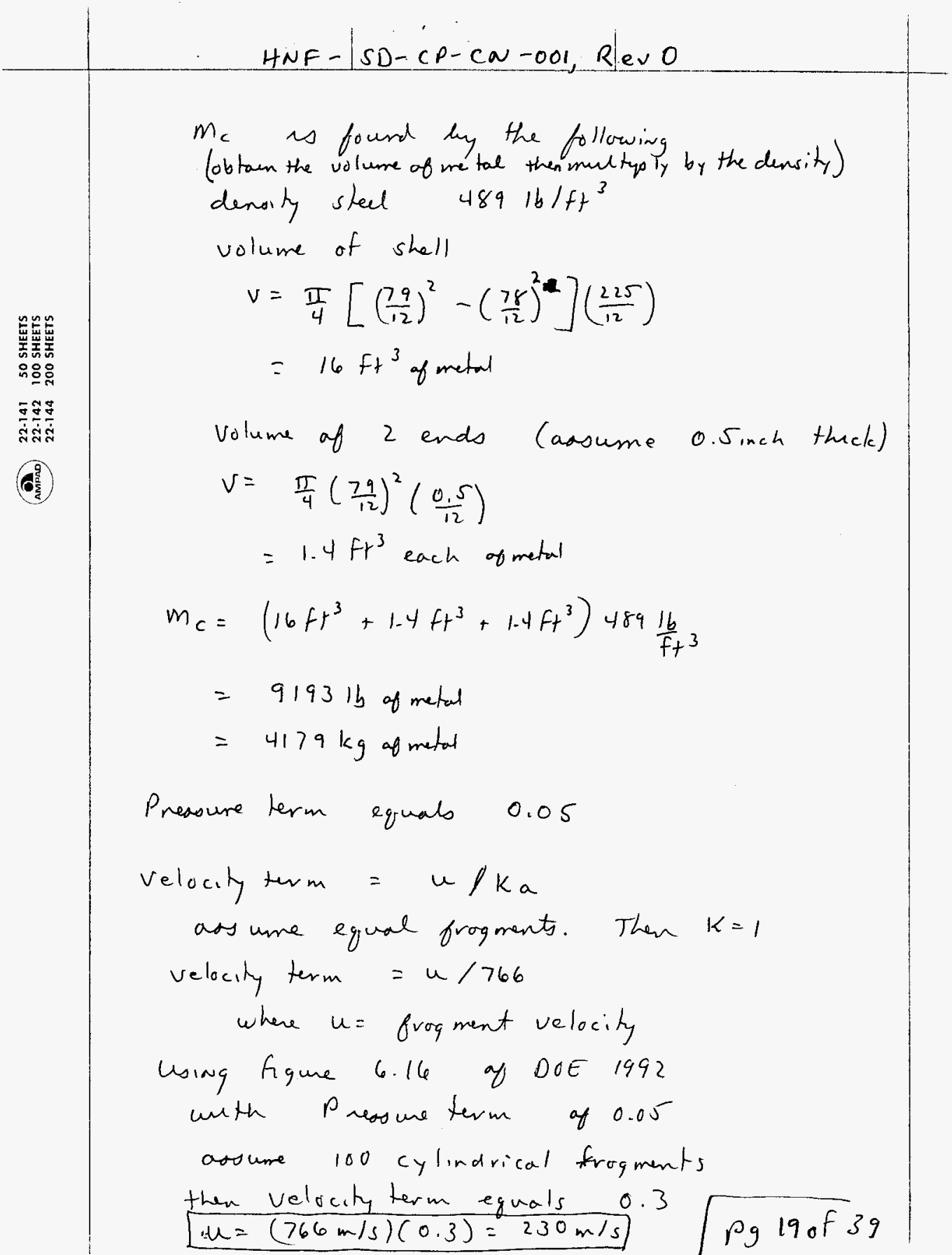




$$
H N F-\mid S D-C P-C N-001, R \text { R NO }
$$

The ability of the fragment to penetrate walls ss taken from Army (1986)

The value $u=230 \mathrm{~m} / \mathrm{s}$ is the initial velocity of the particle. The particle will slow our time.

Figme 6-5 pg 6-10 of Army 1986 shows the rato of the velocity as a function of fragment weight.

At $50 \mathrm{~m}$ (164 ft) large fragments (>1000z) loose utile of their velocity. The figure provides the following information

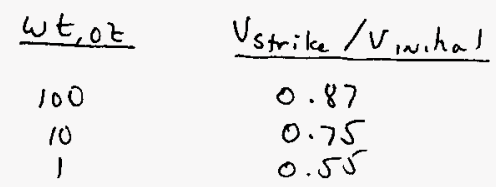

Assure that the strike velocity equals the initial velocity. The is close to true for longe fragments that weigh allot (e) 100 oz w wo). Figure 6-7 pg 6-13 shows the penetration depth as a function of weight and velocity. At $230 \mathrm{~m} / \mathrm{s}$ ( $754 \mathrm{ft} / \mathrm{s}$ ) large frog rents (40.z) con perpetrate up to 1 inch of steel.

Even log fragments can penetrate $0.3 \mathrm{in}$.

pg 20 of 39 


$$
\begin{gathered}
\text { HNF-SD-CP-CN-001, Rev } 0 \\
\text { Pg 6-9 of Army } 1986 \\
\text { provides on equation for striking velocity } \\
V_{\text {strike }}=\left(V_{\text {in. hal }}\right)\left(\exp \left[-0.004\left(R / \omega^{0.333}\right)\right]\right)
\end{gathered}
$$



where $R=$ distance to point of concurs, ft $\omega=$ fragment $\omega t, o z$

Assume a 1000 torment.

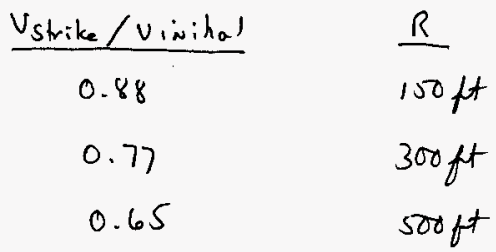

The values of $v_{s}$ trike/vinikal for a $100 z$ fragment are still 0.4 at scoff.

It is un realistic to place the boiler bock for everugh to prevent fragments from entering $234-5 z$ Building of PF P. Instead credit should be tolan for event probability, fragment size (gravity, drag, lack of aerodynamics all will cause the fragment to foll to the ground prior to sticking) and fragment direction (orientation of boiler with respect to 234-5z, fragments will be sent out over a longe solid angle).

$$
\text { pg } 21 \text { of } 39
$$







HNF-SD-CP-CN-001, hew 0

E. Hazards to Personal

DOE (1992) pg 179-196 provide the information. use 2 prig as on avenge of the steel sheet facture purdue and the block value

1. Pg 4-181 colours a graph of lung dore vs oven pleasure ad impulse

over pressure $\bar{p}_{s}=p_{s} / P_{0}$

$$
\begin{aligned}
& =2 \text { psig/14.7 } \\
& =0.136
\end{aligned}
$$

$P_{s}=$ overperosure p sig

$P_{0}=$ atroospteric pressure

This value is below the threshold for all values of impulse.

2. pg 4-189 shows skull fracture velocities as a function of $P_{s}$ and scaled impulse.

In om case

$$
P_{s}=2 p \text { sig }
$$

scaled impulse $\bar{i}=i / \mathrm{m}^{0.33}$

$$
m=\text { equivalent TNT, ib }
$$

From previous calculations $E=3 \times 10^{8} \mathrm{~N}-\mathrm{m}$

$$
3 \times 10^{8} \mathrm{~N}-\mathrm{m}=3 \times 10^{8} \mathrm{~J}=7.2 \times 10^{7} \mathrm{col}
$$

energy of TNT $=1080 \mathrm{cal} / \mathrm{g}$,TNT

$$
\begin{aligned}
7.2 \times 10^{7} \text { cal } & =66,666 \mathrm{~g} \text { TNT } \\
& =147 \mathrm{lb} \text { TNT }
\end{aligned}
$$

Using the heme spherical TNT curves we th

$$
=\quad \omega=147 \mathrm{lb}, R=164 \frac{\mathrm{ft}, \quad z=R / \omega^{0.333}=31 \quad(B a k+)}{\operatorname{pg} 230 \mathrm{~F} 39}
$$




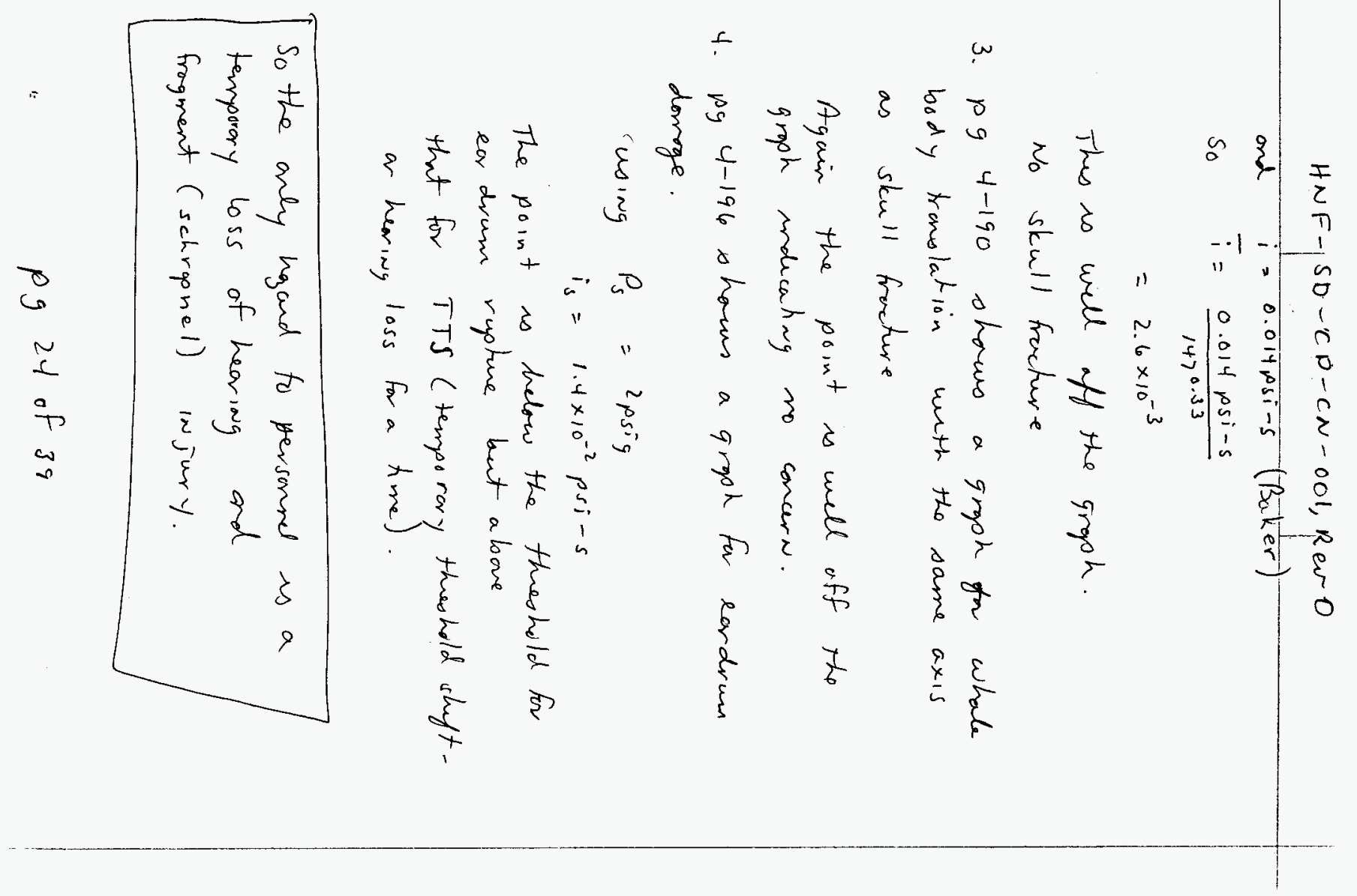




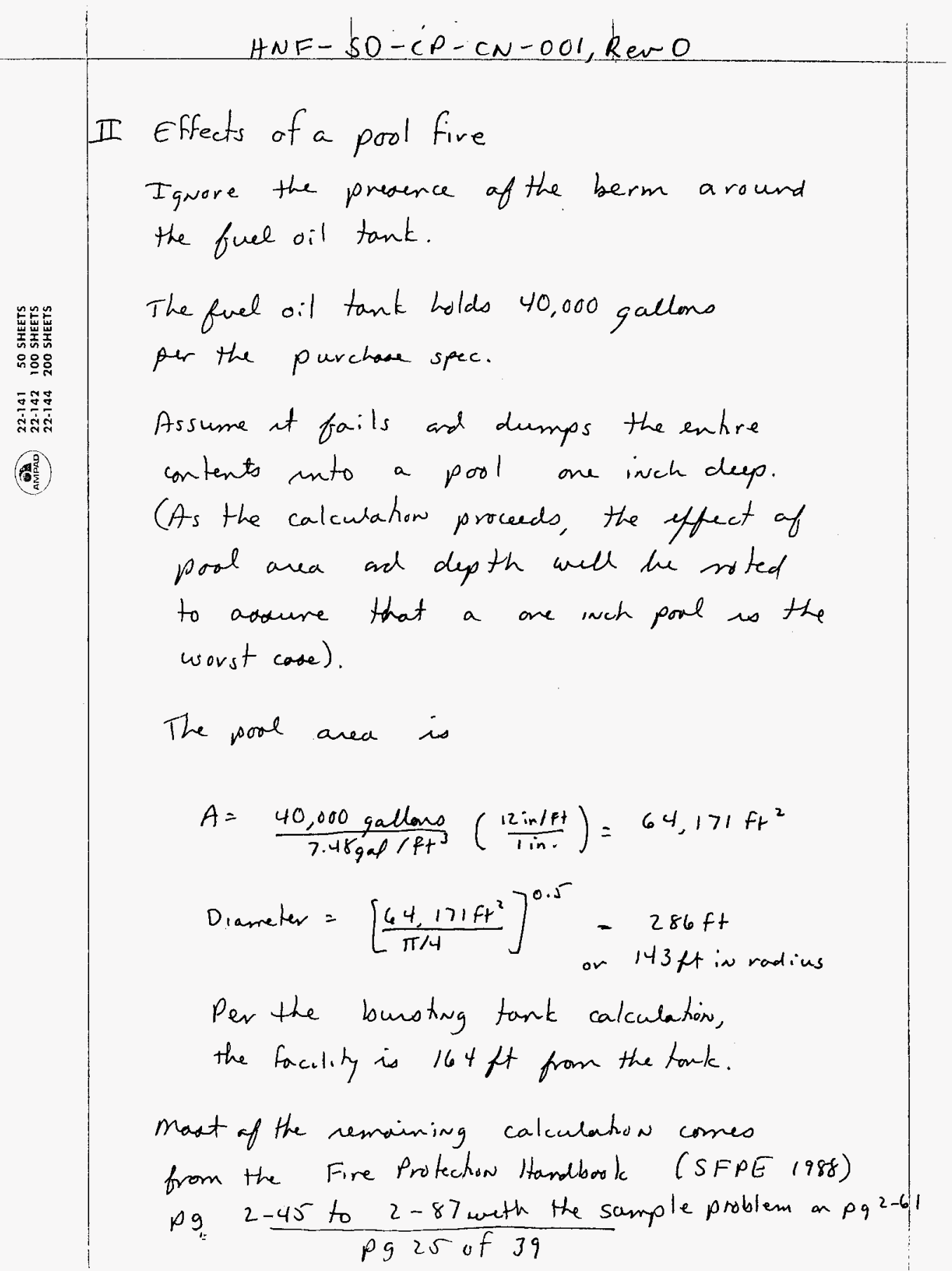




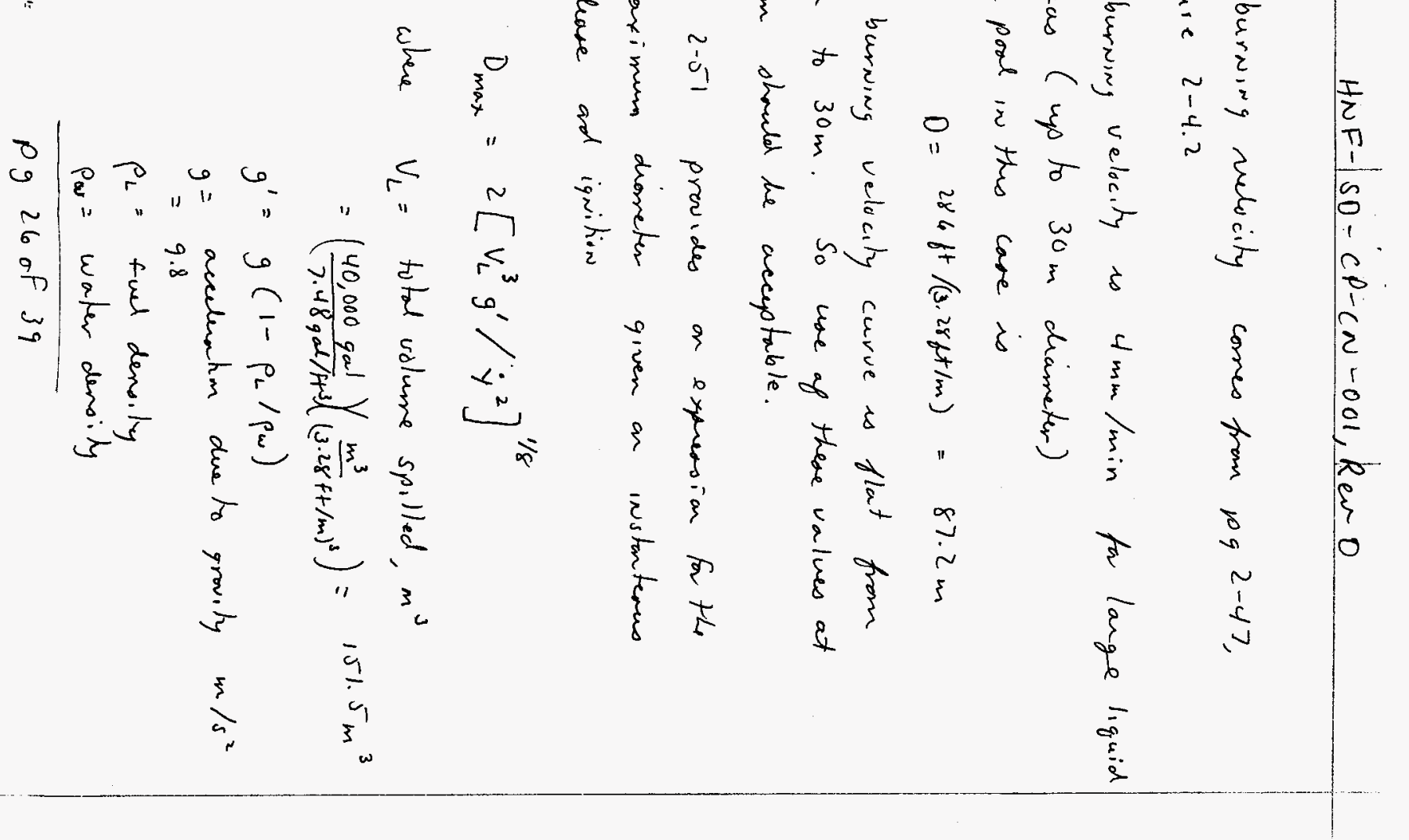




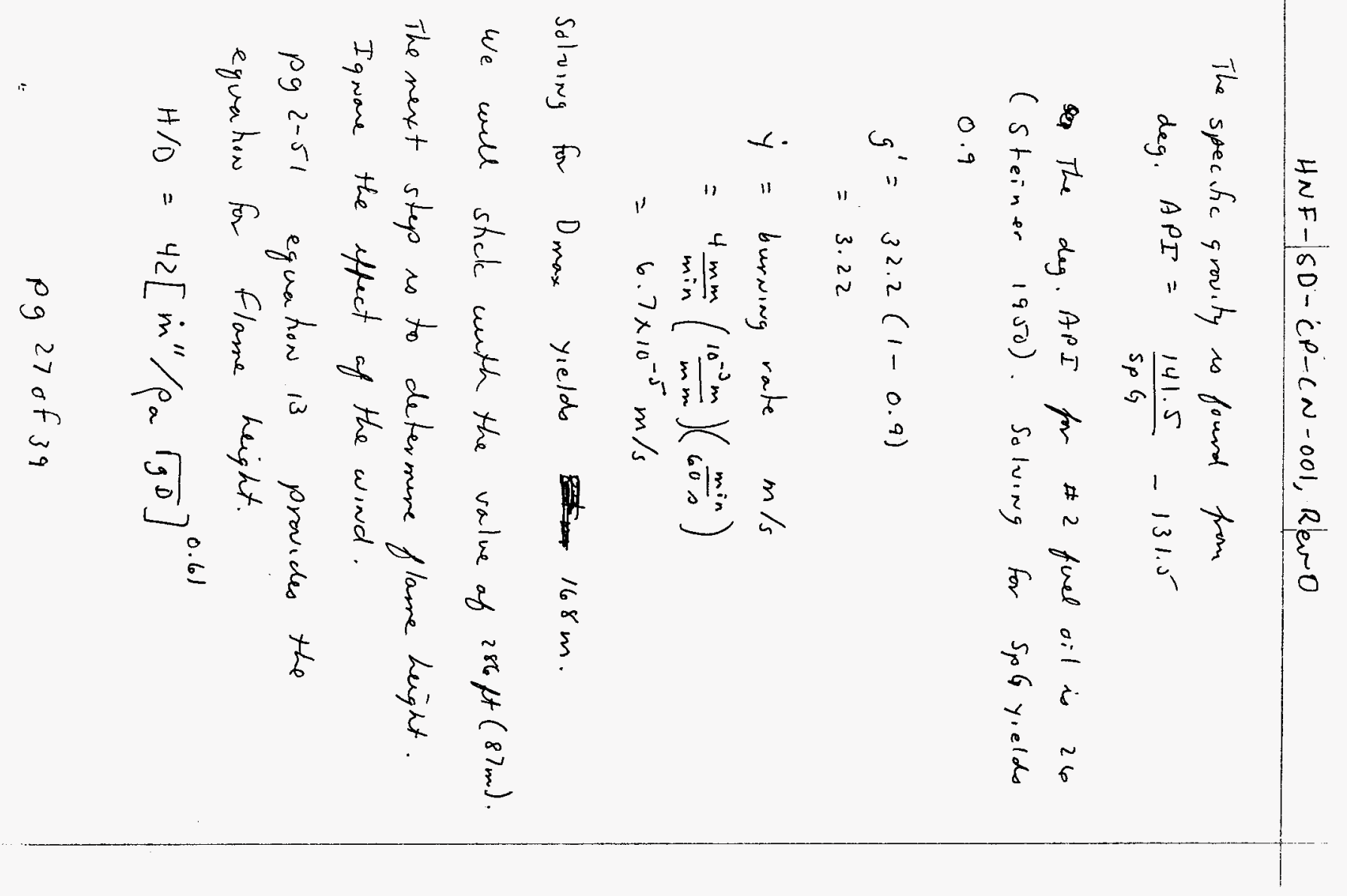




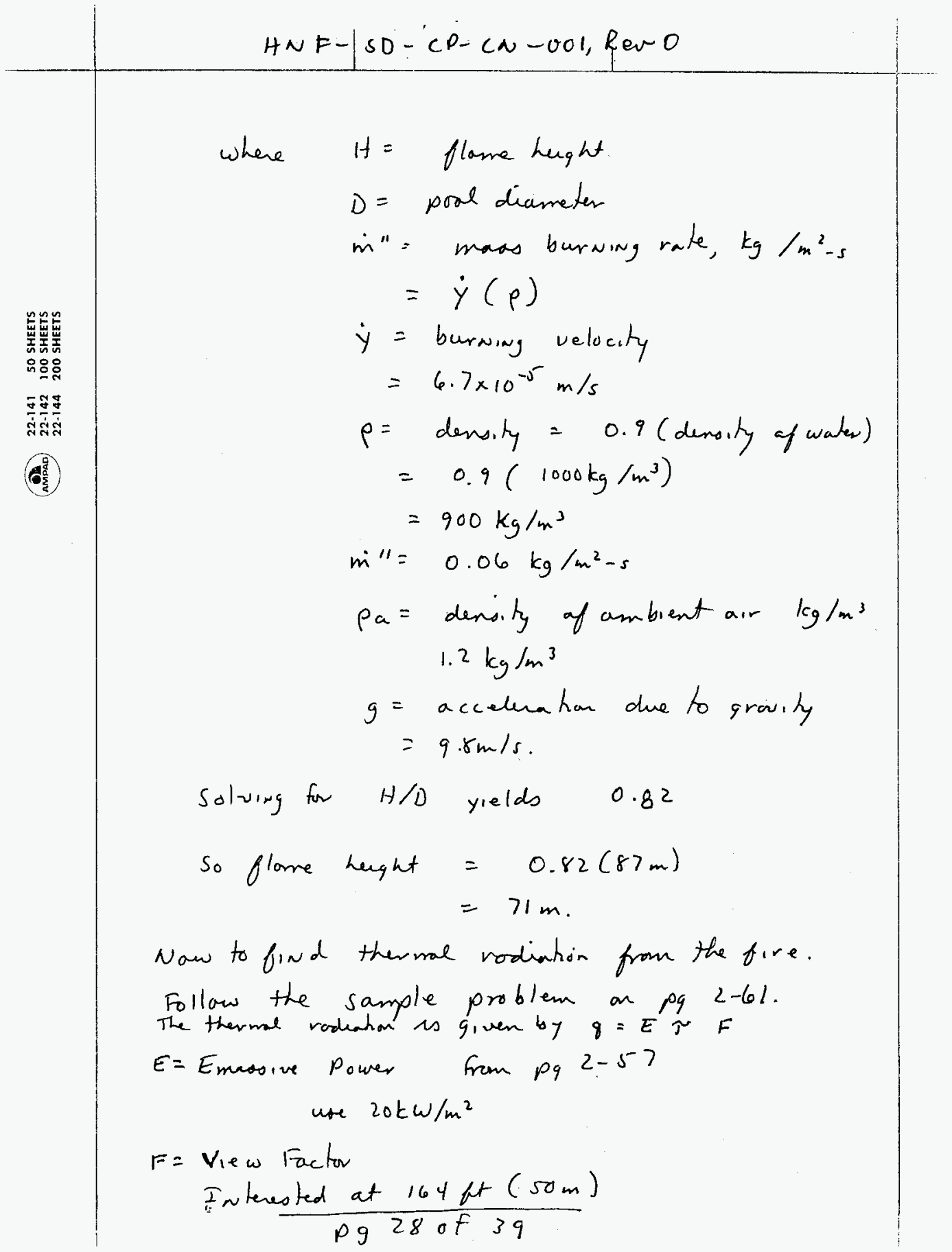




HNF-SD-CP-CN-0O1, Rew 0
Use Figure $2-4.13$
The non-dumersianal destonce is given by

$$
x /(D / 2)
$$

where $X=$ distance forn center of por 1 to point of interest

$$
\begin{aligned}
& =50 \mathrm{~m} \\
D & =\text { pool deameter }=87 \mathrm{~m}
\end{aligned}
$$

Non-Dimensiarl destance $=1.10^{-}$

Henght to rodius ratio $=(71 \mathrm{~m}$ tolle $) /(87 \mathrm{~m} / 2)$

$$
=1.6
$$

The view factor equals 0.5 $\tau=$ transinusivity

Next the tronominsivity as fourd

Fique 2-4.20 gives the tranomiosivity

as afunctoos of path longth ard velative humidily. Assure a value of 0.8 (low humidity value
for transmissivity)

The rodicut heat flux is given by

$$
q=E_{p} \tau F
$$

where $E_{p}=E_{\text {messive }} P_{\text {ouver }}=20 \mathrm{k \omega} / \mathrm{m}^{2}$

$\tau=$ tromomessivity $=0.8$

$F=$ view foctor $=0.5$

$q=8 \mathrm{kw} / \mathrm{m}^{2}$

$\operatorname{pg} 29$ of 39 


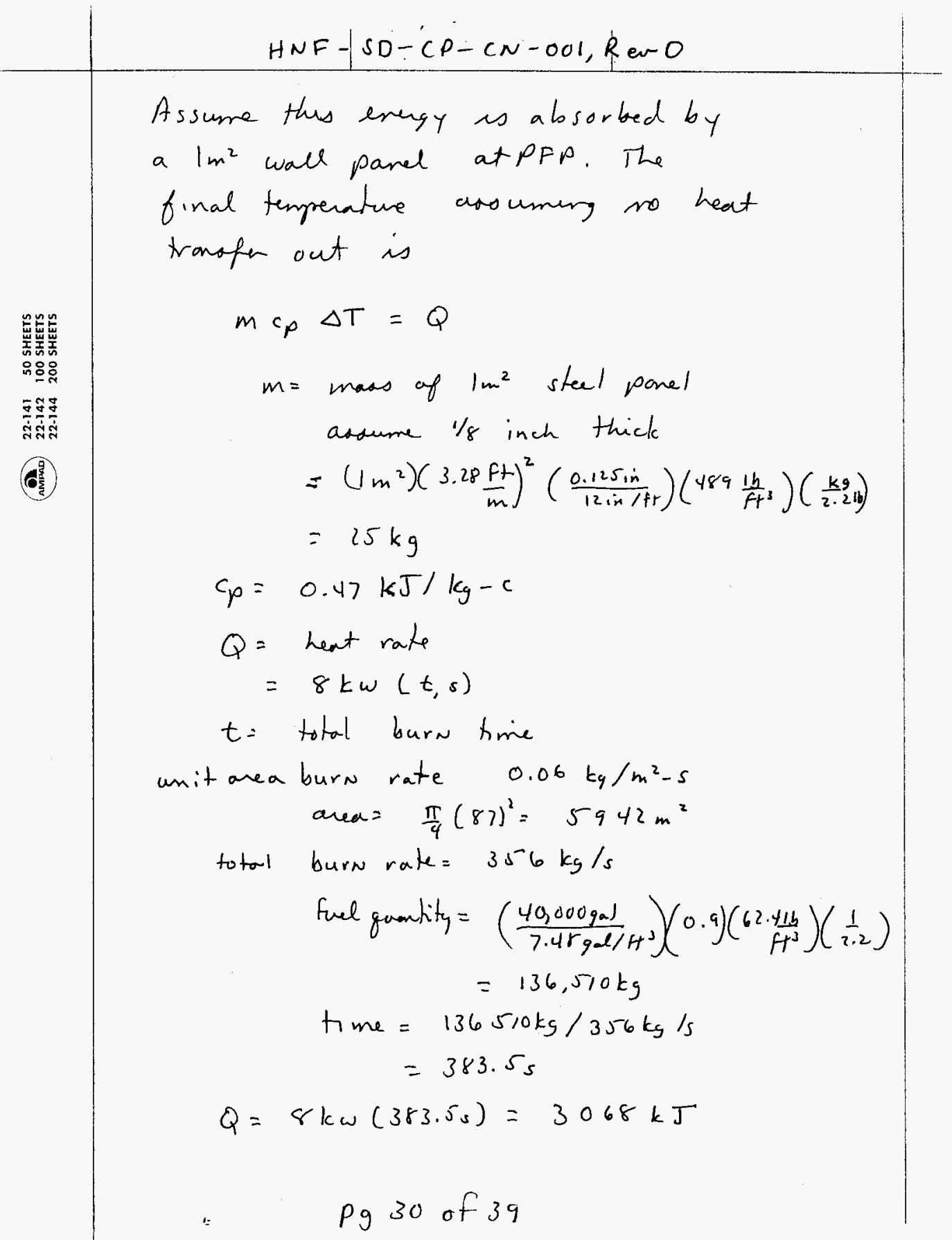







HNF-SD-CD-CN-001, Rev 0

The no clare to $8 \mathrm{kw} / \mathrm{m}^{2}$ so the temperature is $261 \mathrm{c}+30 \mathrm{c}=291 \mathrm{c}$

$$
=556 \%
$$

Thus is probably er rough to exceasinly heat the modulation and possibly hove it catch fine. A pool $87 \mathrm{~m}$ large must he avoided.

Check the berm

The berm is 100 in tall

16 ft wide (actually $15^{-1} 8^{\prime \prime}$ )

4) ft long

The pool effective diameter is

$$
\begin{aligned}
\frac{\pi}{4} D^{2} & =\frac{(16)(47)}{(3.28)^{2}} \\
D & =9.4 \mathrm{~m}
\end{aligned}
$$

substituting thus into the H/D equation yields 1.7

$$
\begin{aligned}
& H=1.7(9.4 \mathrm{~m})=16 \mathrm{~m} . \\
& E=20 \mathrm{k \omega} / \mathrm{m}^{2}
\end{aligned}
$$

To find $F$.

$$
\begin{aligned}
& x /(D / 2)=50 /(9.4 / 2) \\
& =\frac{H /(0 / 2)=10,6}{P g 32 \text { of } 39}=3.4
\end{aligned}
$$



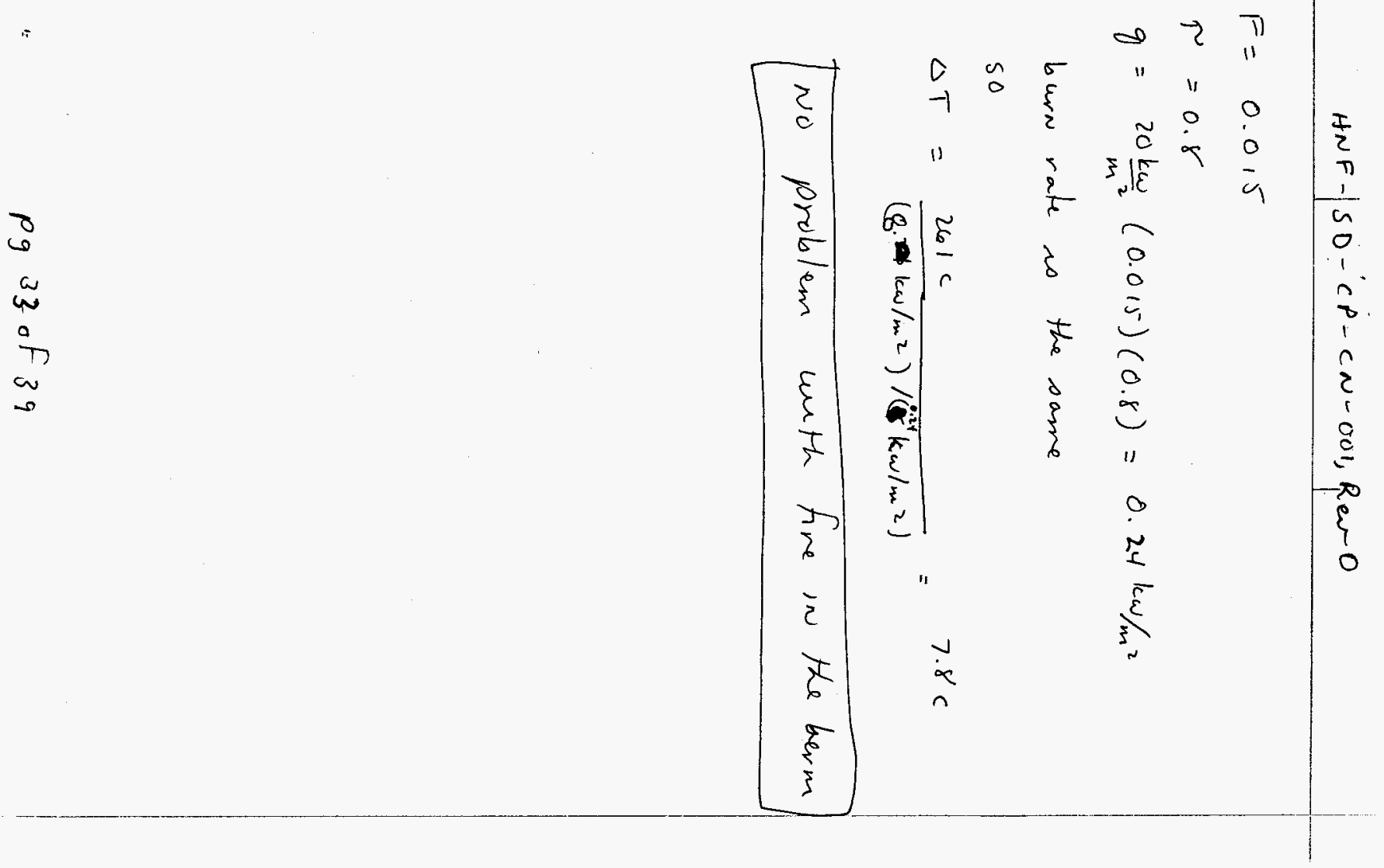









The henght is 18 ft

The volurre is theefore $41,300 \mathrm{ft}^{3}$ wuth no credet taken for volurre taken up by equipment.

Diesel Fuel con be wodelled as being a musture of cetare ( $N$ - hexa decane) ond methyl-naph thalene. It is ardumed that a 50-50 mix of each is the composition. Cetare has a

cetare number of 100 . Methylwaph thatere has a cetare number of 0 . Diesel fuels hove a cetare number of 35-65 (Data from Pq 375, kirk-Othmer 1994)

$\operatorname{pg} 35$ of 39 
HNF-SD-CP-CN-OOI, ReNO

The LFL of cetane is $0.43 \%$ by volume (n sing N-hexadecane for cetane) or 4 ingle as aerosol droplets.

The UFL is rat given

The flammability lime ts far jet fuel are

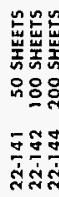

LFL

$1.4 \%$

$48 \mathrm{mg} / \mathrm{l}$

URL

89

$330 \mathrm{mg} / \ell$

(Data from Zabetatis 1965)

Assume that the stochometric mixture is

$2.8 \%$ (double the LFL) Kanury 1975

The room volume is $41,300 \mathrm{ft}^{3}$.

The volume of flammable gas is

$$
v=0.028\left(41,300 \mathrm{Ft}^{3}\right)=1156 \mathrm{ft}^{3}
$$

The molecular weight is a bout $120 \mathrm{~g} /$ role

(kanury 1975 based on gasoline, jetfucl)

The quantity of vapor is found using the ideal gas law.

$$
\begin{aligned}
& \rho V=n R T \\
& (1 \mathrm{~atm})\left(1156 \mathrm{ft}^{3}\right)=N\left(0.73 \text { atm } f_{f}^{3}\right)(460+70 \mathrm{~F}) \\
& N=2.99 \mathrm{lbmoles} \\
& =1357.5 \mathrm{gmoles} R \\
& m=N(M 01 . \omega t .) \\
& =\frac{1357.5(120 \mathrm{~g})=162,900 \mathrm{~g} \text { of gas }}{\operatorname{pg} 360 \mathrm{f} 39}
\end{aligned}
$$




$$
\text { HNF- SD-CP-CN- OO1, Rew }
$$

If we ure dauble the oevsol looding at LFL as the stoichometric condution we get

$$
m=\left(\frac{88 \mathrm{mg}}{l}\right)\left(\frac{\mathrm{g}}{1000 \mathrm{mg}}\right)\left(41,300 \mathrm{Ft}^{3}\right)\left(\frac{28.3 \mathrm{fl}}{\mathrm{ft}^{3}}\right)=102,900 \mathrm{~g}
$$

or just about two-thinds the gas looding.

Since it is mave lukly that aersol well be released thon gas, the aersol lood will be used.

The enargy seleved is $10.3 \mathrm{kcal} / \mathrm{gm}$ (Konury) The total energy released is $1.06 \times 10^{6} \mathrm{kcal}$.

The overparame at someters so found from kugarko (1966)

Kogarko provides puesure as a furction of destance from expluding spherical ballouns.

The ovenpreasure is given by

$$
\begin{gathered}
\Delta p=0.6 \times 10^{-3} \frac{E^{1 / 3}}{R}+1.4 \times 10^{-2} \frac{E^{2 / 3}}{R^{2}}+2.5 \times 10^{-3} \frac{E}{R^{3}} \\
\text { for } \frac{R}{E^{1 / 3}}>0.3
\end{gathered}
$$

where $R=$ destance from center to point of unterest, $m$

$$
E=\text { erengy, kcal }
$$

$\Delta p=\frac{k q}{\mathrm{css}^{2}} \sim$ ator puroune defferentiol 
HNFF SD-CP-CN-001, ReNO

In our case

$$
\begin{aligned}
& E=1.06 \times 10^{6} \mathrm{kcal} \\
& R=50 \mathrm{~m}
\end{aligned}
$$

$$
\begin{aligned}
\Delta p & =0.0012+0.058+0.021 \\
& =0.08 \mathrm{~atm} \\
& =1.2 \mathrm{psi}
\end{aligned}
$$

The is leas than the areupuodure due to vessel over pressurization by a 5 mall arrount (1. 5psi us 1.2 psi). Therefore $50 \mathrm{~m}$ siting is acceptable

Use of $160,900 \mathrm{~g}$ of $g$ as at $10.3 \mathrm{kcal} / \mathrm{g}$ in the method in Kogarto (1966) yields 1.7 psi. The is clove enough to 1.5 psi that the site $50 \mathrm{~m}$ away is shill acceptable based on all of the conservations in the calculation.

$$
p q 38 \text { of } 39
$$




\section{HNF-SD-CP-CN-OO1, Rer $O$ \\ CHECKLIST FOR PEER REVIEW}

Document Reviewed: "PACKAGE BOILER SITING CALCULATIONS - VESSEL OVERPRESSURIZATION," June 5, 1997.

Scope of Review: Entire Document

Yes No NA

[ ] [ ] $[X]$ * Previous reviews complete and cover analysis, up to scope of this review, with no gaps.

[X] [ ] [ ] Problem completely defined.

$[x][][[]$ Accident scenarios developed in a clear and logical manner.

[X] [ ] [ ] Necessary assumptions explicitly stated and supported.

[][]$[x]$ Computer codes and data files documented.

$[x][][]$

$[x][][]$

Data used in calculations explicitly stated in document.

Data checked for consistency with original source information as applicable.

[X] [ ] [ ] Mathematical derivations checked including dimensiona] consistency of results.

[X] [ ] [ ] Models appropriate and used within range of validity or use outside range of established validity justified.

[x] [ ] [ ] Hand calculations checked for errors. Spreadsheet results should be treated exactly the same as hand calculations.

[ ] [ ] [X] Software input correct and consistent with document reviewed.

[][]$[x]$ Software output consistent with input and with results reported in document reviewed.

[X] [ ] [ ] Limits/criteria/guidelines applied to analysis results are appropriate and referenced. Limits/criteria/guidelines checked against references.

[X] [ ] [ ] Safety margins consistent with good engineering practices.

$[X][][]$ Conclusions consistent with analytical results and applicable limits.

DX] [ ] [ ] Results and conclusions address all points required in the problem statement.

[ ] [ ] [X] Format consistent with appropriate NRC Regulatory Guide or other standards

[ ] [X] * Review calculations, comments, and/or notes are attached.

\section{[X] [ ] [ ] Document approved.}






\begin{tabular}{|c|c|c|c|c|c|}
\hline \multicolumn{6}{|c|}{ DISTRIBUTION SHEET } \\
\hline \multirow{2}{*}{$\begin{array}{l}\text { To } \\
\text { Distribution }\end{array}$} & \multirow{2}{*}{\multicolumn{3}{|c|}{$\begin{array}{l}\text { From } \\
\text { R. M. Marusich, } \\
\text { Fluor Daniel Northwest }\end{array}$}} & \multicolumn{2}{|c|}{ Page 1 of 1} \\
\hline & & & & \multicolumn{2}{|c|}{ Date June 10,1997} \\
\hline \multicolumn{4}{|l|}{ Project Title/Work Order } & \multicolumn{2}{|c|}{ EDT No. 621242} \\
\hline \multicolumn{4}{|c|}{$\begin{array}{l}\text { Package Boiler Siting Calculations - Vessel overpressurization } \\
\text { and Fuel 0il Fire }\end{array}$} & \multicolumn{2}{|c|}{ ECN No. N/A } \\
\hline Name & MSIN & $\begin{array}{l}\text { Text } \\
\text { With All } \\
\text { Attach. }\end{array}$ & $\begin{array}{l}\text { Text } \\
\text { Only }\end{array}$ & $\begin{array}{l}\text { Attach./ } \\
\text { Appendix } \\
\text { Only }\end{array}$ & $\begin{array}{l}\text { EDT/ECN } \\
\text { Only }\end{array}$ \\
\hline B. W. Hall & & A3-34 & $x$ & & \\
\hline B. E. Hey & & A3-34 & $x$ & & \\
\hline R. M. Marusich (3) & & $A 3-34$ & $x$ & & \\
\hline D. G. Murillo & & $A 2-45$ & $x$ & & \\
\hline A. L. Ramble (2) & & T5-54 & $x$ & & \\
\hline J. E. Shapley & & $A 2-25$ & $x$ & & \\
\hline Central Files (original +2 ) & & A3-88 & $x$ & & \\
\hline
\end{tabular}

